\title{
ESSAY
}

\section{The Smallness of Identity, Smallness of Blackness}

\author{
Edda Fields-Black \\ Carnegie Mellon University, US \\ fieldsblack@cmu.edu
}

Edda Fields-Black reflects on growing up Black in Miami and how it has shaped her intellectual pursuits.

Keywords: Bahamian; Gullah Geechee; Brownsville; middle class; smallness of identity

When I was growing up, you could not have told me that University of Miami was not our back yard! If you did, I would not have believed you. We were "Hurricanes" through and through, even though my grandmother, the late Dorothy Katherine Johnson Jenkins McKellar, was rejected when she applied for graduate admission in 1955; UM like many colleges and universities in the U.S. South during the Jim Crow era was still segregated. My cousin on my mother's side of the family, Dr. Whittington Johnson, broke racial barriers as University of Miami's first Black professor, hired in 1970. Dr. Johnson served as chair of the History Department three times, beginning in 1976. At one time, he was the only Black faculty member in the entire 364-member College of Arts and Sciences.

My father, Eddie Fields, graduated from University of Miami Law School with a JD in 1977, when I was five years old, and an LLM in 1978. Most Sundays after church, Daddy drove with my sister, Katherine, and me to UM's law library. He worked for several hours, while we played in our "backyard." In the days of helicopter parenting when cell phones have replaced umbilical cords, it is hard to believe that my father would give my sister, who is just two years older than me, a few dollars, no instructions or supervision, and turn us loose onto the UM campus by ourselves. We enjoyed the freedom of going to the student union to bowl, play video games in the arcade, and eat junk food. We also frequented the lakes on campus where we watched alligators and turtles climb up on the rocks and sun themselves. I don't remember the reality that we could have been alligator bait ever crossing my mind. Daddy never told us what time to meet him back at the law library; there were no cell phones, so we could not call or text. Eventually, Katherine and I would run out of money, get bored, and/or start fighting, usually all of the above, and we would wander back to where Daddy was working. It seemed that we always arrived right on time, just as he was packing up to go home. My Dad is also an avid football fan; we had season tickets to the Hurricanes' football games. For most of my childhood, we spent most Saturdays during football season at the Orange Bowl, watching the Hurricanes play.

My first book, Deep Roots: Rice Farmers in West Africa and the African Diaspora, traces the indigenous evolution of coastal rice-growing practices as an outgrowth of coastal land-use systems dating back to antiquity. The confluence of interdisciplinary evidence attests to coastal specialists, the first-comers who were indigenous to the coastal region, and the newcomers who migrated from the forest-savanna adjacent to the coast, as the architects of coastal rice-growing technology. It presents a rare picture of the highly-localized scale on which change took place in dynamic pre-colonial West African societies, which I'll call here the "smallness of identity." After applying new interdisciplinary tools and methods to understanding the dynamic and localized nature of change in pre-colonial West African societies, my second monograph, tentatively titled, 'Combee': Harriet Tubman, the Combahee River Raid, and the Civil War Transformations of Gullah Geechee, is poised to make another unique contribution, this time to an important transnational literature of the African Diaspora, through the history of the Gullah Geechee. A related set of questions are at the core of my new research: How can historians understand how people of African-descent created new cultures and 


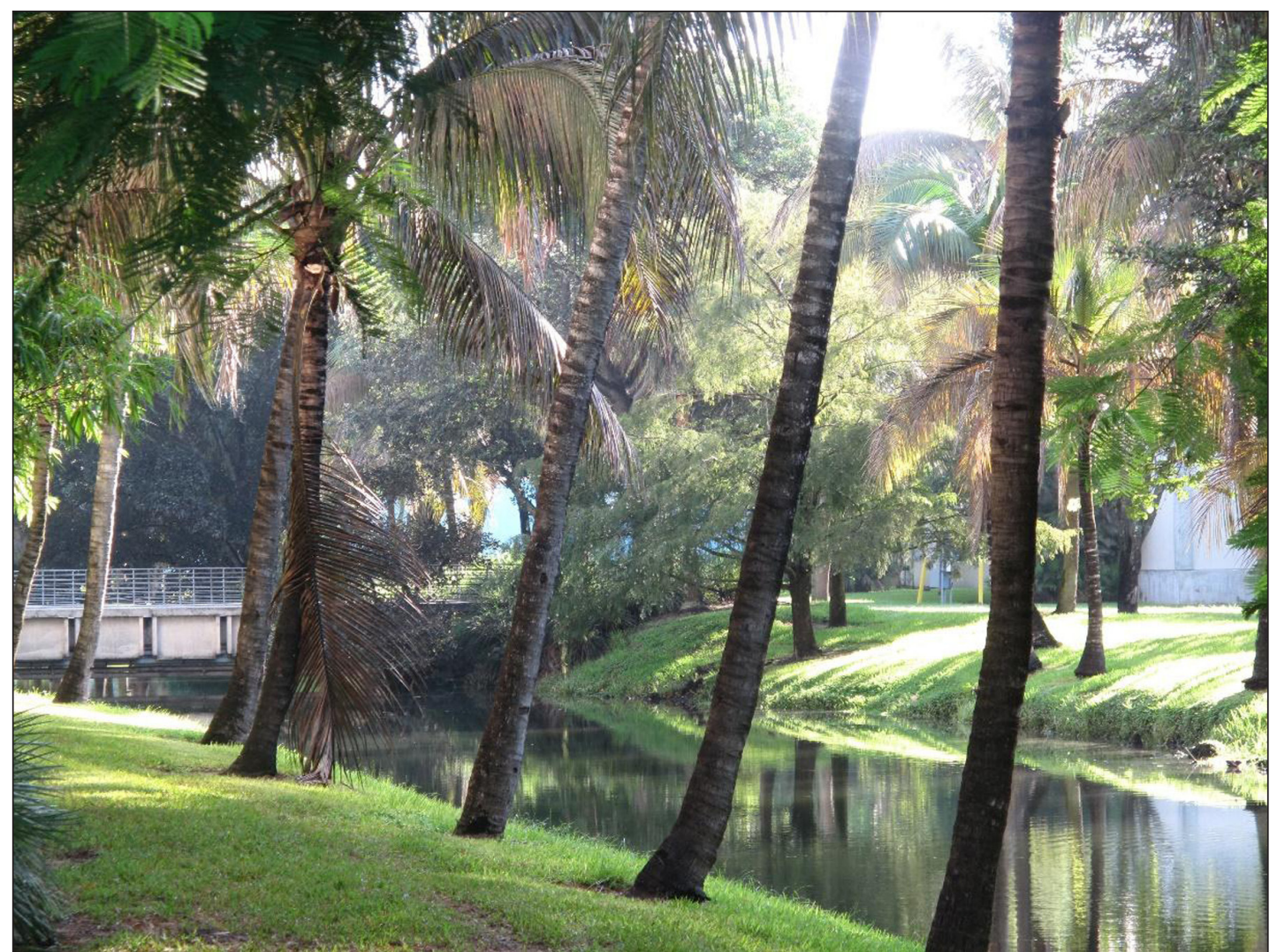

Canals that criss-cross University of Miami's campus. Copyright @ 2011 , University of Miami.

languages in the New World? And, how can historians understand the creolization process from the perspective of enslaved and freed Africans who left few documents in their own hand? I have spent much of my graduate education and academic career curious about how dynamic West African societies identified themselves in the pre-colonial period, how people of African descent created new creole cultures and languages in the New World, and how historians can tell these stories when Blacks on both sides of the Atlantic left so few historical sources written in their own hands. In hindsight, in many ways, growing up Black in Miami in the 1970s and 1980s made an early imprint on me and would shape my curiosity and my career until today.

My maternal great-grandparents emigrated from the Bahamas to Key West, FL in the late 1890s. My greatgrandfather, Sam. D. Johnson, worked as a sponger and my great-grandmother, Ida Ellen Johnson, worked as a domestic for a white family. My great-grandmother read in periodicals at the home where she worked about schools for Black children in the U.S. She very much wanted her children to be educated. My greatgrandparents' two oldest children, Samuel H. Johnson and Elaine Johnson Adderley, were born in Key West, and then the young Johnson family continued along its journey to Miami, where six more children were born, including my grandmother. They settled in and lived in Overtown until the Johnson family moved to Brownsville, where my grandmother and each of her siblings bought homes on 2 adjacent blocks, establishing a Bahamian yard. My Uncle Ken owned a home on the block, but lived in a second home 12 blocks away. I grew up with my grandmother's home adjacent to our house; the backs of our houses faced each other separated by an unfenced yard. My grandmother's seven brothers' and sisters' homes were adjacent to hers. My big sister, Katherine, and I only had and only needed a babysitter once in our entire growing up years when we were on vacation with our parents in Ocho Rios, Jamaica.

My paternal grandparents lived in Green Pond, SC, where my father was born. Green Pond is located in Colleton County, SC about an hour south of Charleston and 30 minutes north of Beaufort, in what has been designated the Gullah Geechee Cultural Heritage Corridor. The Fields family migrated from a rural small-town to what must have seemed like the booming metropolis of Miami sometime in the 1940s. My grandparents and their children lived first in Liberty Square Housing Project, then purchased a home and moved to Opa-Locka. When I was a child, my parents took my sister and I to Opa-Locka a few weekends per month to visit our grandparents. Katherine, my mother, and I would sit in the Florida Room and try to follow my father's conversation with my grandparents. My father spoke standard English to his parents; I never 
heard him speak anything else. I never heard my grandparents, on the other hand, speak standard English. Instead, they spoke to my father in their language, which he understood and then responded in standard English. And, my sister, mother, and I didn't understand my paternal great-grandparents at all when they spoke to each other and my father. We watched their conversation as if watching a tennis match only able to pick out a few words here and there. In college, I learned about Gullah Geechee, a creolized language and culture among African-Americans and the descendants of Blacks enslaved in the coastal areas from Cape Fear River, NC to St. John's River, FL and learned my grandparents spoke the Gullah language.

This makes me the great-granddaughter of immigrants and the granddaughter of migrants. As an adult and a university professor who has many first-generation American undergraduate students, I am struck by how similar the two experiences are. Or, better yet, how similar the experiences of first-generation immigrant and migrant children are vis-à-vis their parents. In our family, only certain occupations were acceptable. Our parents drilled into Katherine and I that we needed to pursue law degrees and join the family business, our father's law firm. My father, in particular, valued entrepreneurship and looked down on people who worked for someone else. Neither interested me from a relatively early age. I chose, instead, to follow in my mother's footsteps and pursue a career in education, historical research, and writing. Though I was shaped and nurtured by my mother's family and grew up in intimate contact with them, I chose subject matter related to my father's family as the topic of my historical research: Creolization, the Gullah Geechee, and rice. In many ways, I still feel like the young child sitting on the settee in my paternal grandparents' Florida Room in Opa-Locka struggling to understand the conversation. Not being able to haunted me for years.

As I reflect on my upbringing, I also remember my mother talking about how she felt before she and my father married when she first met Daddy's family. My mother is two years older than my father; his mother expressed disappointment I am told at my father's choice. My grandmother had wished that my father would have married a younger woman, someone who could cook and someone she could train. There also seemed to have been some tension over the fact that my mother's family were Bahamian immigrants, very ironic coming from Lowcountry migrants. A Geechee and a 'Sau (i.e. Nassau), both were fighting words. Sometimes Blacks who disembarked slaving vessels in different ports and at different moments in time have trouble seeing themselves and each other.

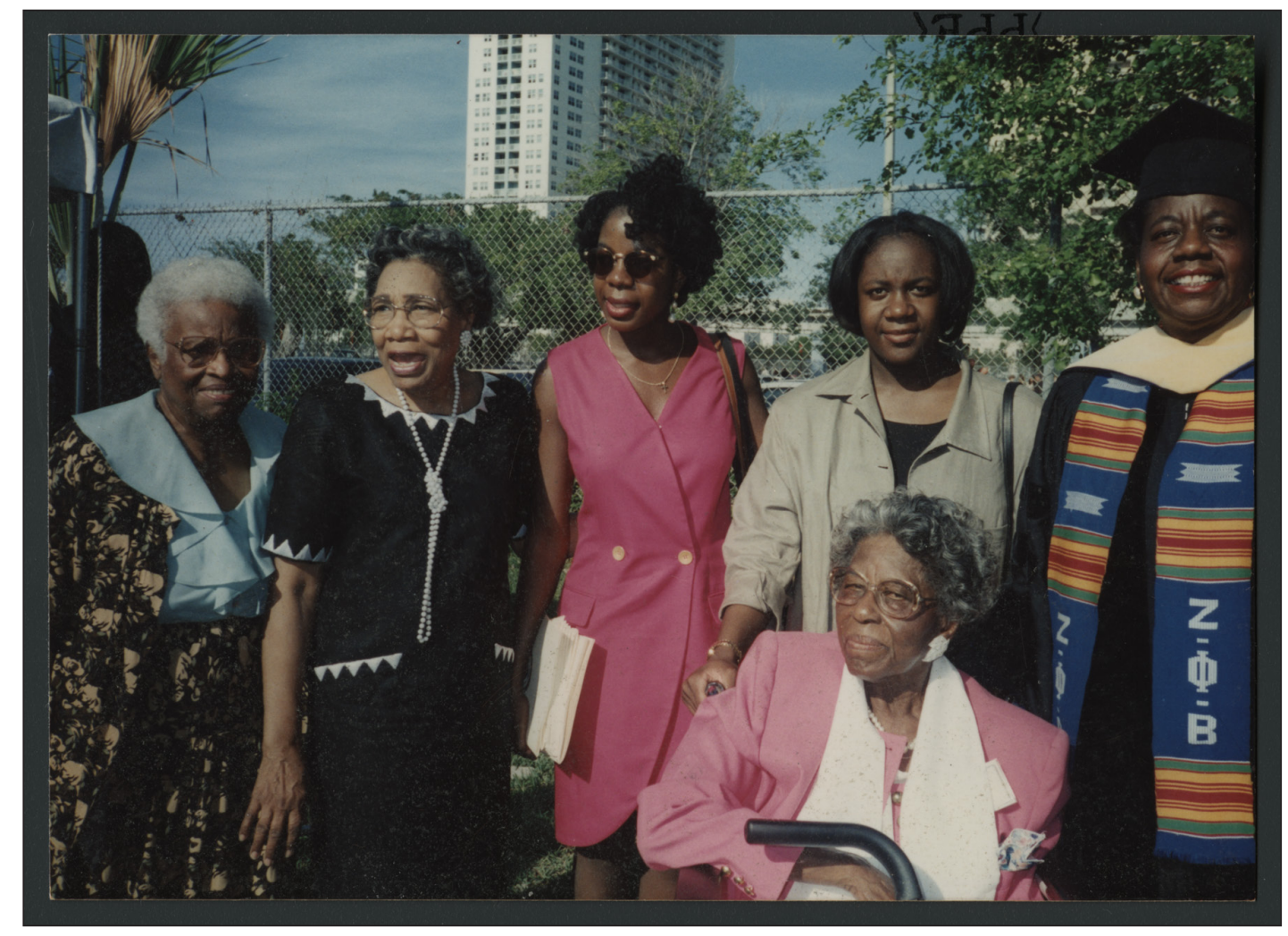

The Johnson and Fields Women: Several generations of Edda Fields-Black's matriarchs gather upon the granting of an honorary degree to Dr. Dorothy Jenkins Fields from Florida International University in 1995. Photo courtesy of the Black Archives. 
My grandmother's eldest brother, Samuel H. Johnson, was the patriarch of the Johnson family. Uncle Sammie attended ninth grade at Florida Baptist Academy in 1913-1914, then Florida Agricultural \& Mechanical College (FAMC and currently FAMU) where he graduated high school in 1919, because there were no high schools for Blacks in Miami at the time. He matriculated to Morehouse College, which he attended 1920-1923. After passing the entrance exam for medical school, but without graduating from Morehouse, he matriculated to Meharry Medical College in 1925. Like all of my grandmother's siblings, Uncle Sammie interrupted his studies in certain years to work to earn money for his and his younger siblings' tuition, room, and board. Uncle Sammie made sure that his siblings were well educated also. The older siblings would go to school for a year, then sit out and work for a year to earn money for their own and a younger sibling's tuition, room, and board. Some of the siblings, like Aunt Bert (Roberta Thompson), required a hands-on approach. Aunt Bert weighed about 90 pounds soaking wet much of her life. When she refused to go back to Tuskegee, Uncle Sammie threw her over his shoulder and put her on the train to Alabama, according to family lore. In the end, all finished college: Aunt Laine (Elaine Adderley) graduated from FAMC in 1937 after completing extension courses at Booker T. Washington High School in Miami; Uncle Fred (Frederick Johnson) graduated from Morehouse College in 1929; Aunt Bert (Roberta Thompson) did graduate from Tuskegee in 1928; my grandmother and her brother Uncle Ken (Dr. James K. Johnson) graduated from FAMC in 1934; and, Uncle John (Judge John Johnson, ret.) graduated from West Virginia State in 1937. They would also matriculate to graduate and professional schools, then return to Miami to serve their community. Uncle Sammie returned to Miami as one of the first Black radiologists in the State of Florida. After completing a fellowship in radiology at Homer G. Philips Hospital in St. Louis, MO in 1937, he established an independent x-ray clinic in 1939, the first private clinic for Blacks in Miami.

Uncle Sammie was the architect of the family's progress at every step of the way. Though the family was established in Overtown, Uncle Sammie scouted out land in Brownsville. Under Uncle Sammie's direction, the Johnson family migrated out of Overtown to Brownsville, which had been farmland and still looked and felt like the suburbs after World War II. By the 1970s when I was born, these suburbs were taken over by economically depressed pockets and housing projects. Located on the edge of Hialeah and Liberty City, Brownsville became home to a transit hub, the Brownsville Metrorail Station. In addition to the Johnson family, many Bahamian immigrant families called Brownsville home. Our church, The Church of the Incarnation Episcopal Church, located in Brownsville, was an enclave for African-American families of Bahamian descent. We also frequented Brownsville businesses owned by Bahamian-descended families, such as Shakers and Bahamian Connection restaurants.

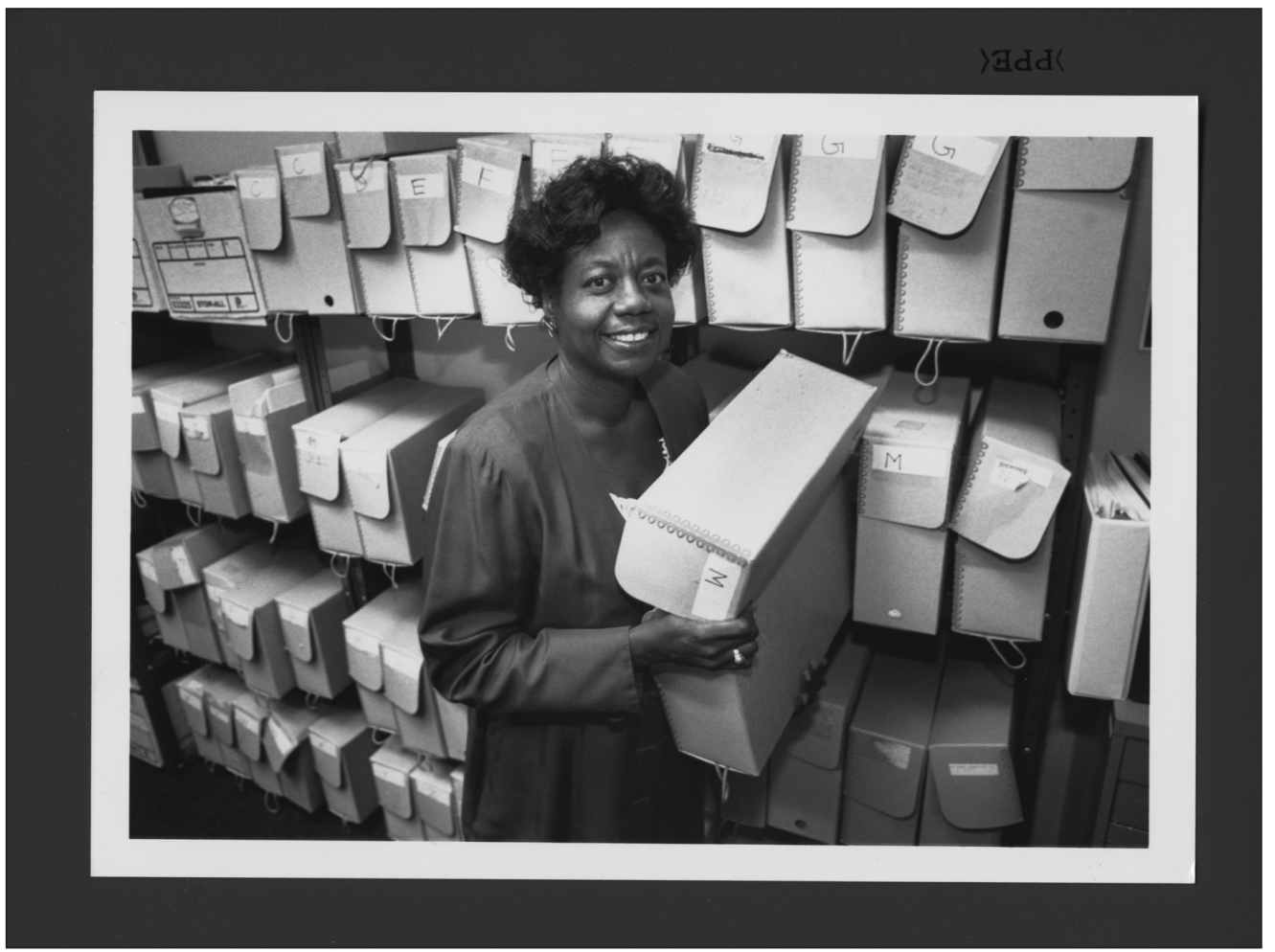

Dr. Dorothy Jenkins Fields, Edda Fields-Black's mother, founded the Black Archives History and Research Foundation of South Florida. Photo Courtesy of the Black Archives. 
When I was in college at Emory University, I had an opportunity to think about my identity, as many college students do. I was surrounded by Black students who proudly wore their Jamaican, Nigerian, and Trinidadian heritage; and, I became angry that my family was not more Bahamian, whatever that means. Sure, we lived in the "yard" and in a neighborhood among other Blacks of Bahamian-descent, supported Bahamian-owned businesses, ate large amounts of conch, and were members of an Episcopal Church. And, I grew up hearing the stories about my great-grandparents sacrificing everything to come to the mainland so that their children could be educated. So what? I wanted to know why my grandmother and her siblings, my mother and her cousins did not act more Bahamian. When I came home for Thanksgiving my sophomore year in college, I was determined to fix this state of affairs. So, shortly before dinner, I decided to show my family how to be Bahamian. I went to Sedano's in Hialeah to buy plantains and fry them for Thanksgiving dinner. The errand took much longer than I expected-the closest Sedano's was closed and I had to venture further out-and I kept everyone waiting. I went to a Cuban-owned grocery in a majority Latinx city to help my family re-discover our Bahamian roots?! The irony is not lost on me today.

On the one hand, my sister and I were insulated and isolated in Brownsville. We never attended neighborhood schools, did not have any friends in the neighborhood, and rarely left the "yard" unless escorted by our parents or another relative. We played outside and sat outside under the mango tree when our cousins came over to visit their grandparents and to play. Otherwise, we were surrounded by our elders who also lived in the "yard" and had no interaction with neighborhood children our age. Simultaneously, by the late 1970s and early 1980s, we could not be insulated. The killing of Arthur McDuffie in Liberty City reverberated through all of Miami's Black neighborhoods. McDuffie's wife and daughters attended The Church of the Incarnation; and, the 1980 Miami Riots in Brownsville, Liberty City, and Overtown came very close to our home. Sometimes, the smallness of identity prevents us from seeing the other.

Zeta Phi Beta sorority was one of my grandmother's greatest loves; and she was an ardent believer in the Zeta's principle of "Finer Womanhood." From the time I was a young girl, Nana inflicted "finer womanhood" on us every chance she got, or at least that's how it felt. It all started with the "Buds of Spring" Cotillion. Sigma Gamma Rho Sorority, Inc., my Aunt Bert's sorority, presented seventh grade girls in a pageant and fundraiser. We learned social graces, such as setting the table, curtsying, and dancing, did community service projects, and raised money by selling ads in a souvenir program showcasing our accomplishments and aspirations. Once the escorts came to practice with us, my escort announced that he had actually wanted to escort another girl. We both attended The Church of the Incarnation and my mother had asked his mother. It felt like an arranged marriage. I was mortified.

My sister's "Buds of Spring" cotillion was cut short by an announcement that motorcyclist Arthur McDuffie had been killed; everyone had to go home immediately. The music went off just as my favorite song, "Special Lady" by Ray, Goodman \& Brown played and the "Buds of Spring" regaled the audience with a dance routine. My mother drove as we cautiously made our way from Bayfront Park back home to Brownsville. The next day, we did not go to the church, nor could we leave the house. My father would not even allow us to open the blinds. Norton Tire Company, located across NW $29^{\text {th }}$ Avenue from my grandmother's house, burned throughout the day, then smoldered for weeks. We were told Norton Tire Company was burned because it was the site of police brutality against Black men. At the end of the day, the posts on our canopy beds were black with soot even though we never opened the windows. The burning of Norton Tire Company and other businesses accelerated Brownsville's decline into a ghetto. We were isolated in our Bahamian yard, but not insulated from the city around us.

In addition to cotillions, our parents gave us a classic middle-class upbringing. My sister, Katherine, and I took swimming lessons at Barry College where Coach Neil Miller threw me in the pool at age 4 or 5 and worked on making me a strong and skilled swimmer for several summers in a row. My father took us to and from swimming lessons. He paced up and down the length of the pool in his three-piece suit while we swam. We got our hair done at Ms. Murray's Golden Hands Beauty Salon in North Miami, then at Ms. Murray's home in Liberty City, every two weeks. We were members of Jack and Jill of America, Inc. from the time we were Tiny Tots until we graduated from high school, attending meetings during the school year and regional conferences over the summer. After the "Buds of Spring," the next stage was Debutants, sponsored my grand-godmother Dorothy Graham's chapter of Delta Sigma Theta Sorority, Inc. We began in $9^{\text {th }}$ grade preparing for our presentations in $12^{\text {th }}$ grade. Every Sunday, for four years, we were called to meet and show our dedication to learning social graces. It felt to me like a life sentence. Debs met at the same time as the South Florida Youth Symphony's rehearsals in North Miami Beach; and, I loved playing 


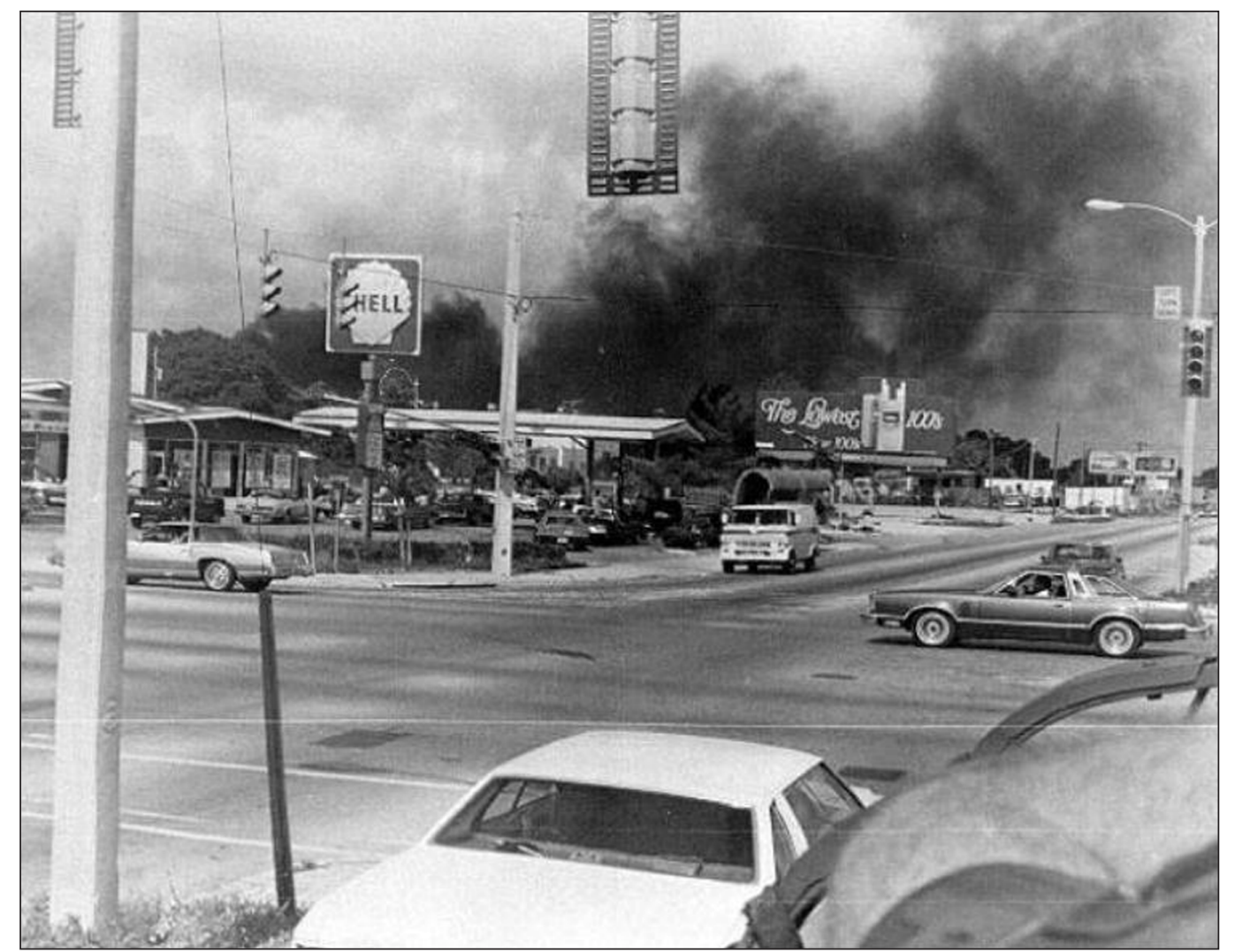

Fire after McDuffie Riots: Black smoke billows from a fire set when rioting occurred in Miami on the acquittal of four police officers who beat Black businessman Arthur McDuffie to death. Photo courtesy of the State Archive of Florida.

with the youth symphony. I could not imagine spending every Sunday for four years learning social graces when I was devoted to my beloved flute and did not have the opportunity to play in a band or ensemble at school. So, in $10^{\text {th }}$ grade, to the horror of Mom's family, I quit debs and retired from finer womanhood. Enough was enough.

At Church of the Incarnation, Jack and Jill, Buds of Spring, and debs, I never fit in, because we were different from all the other kids. We spoke differently-I was routinely called an Oreo by other children, because of the way I spoke, proper, standard English; we lived in a different neighborhood than the other kids and were socially awkward. That we had very strict parents did not help matters. We weren't allowed to socialize with other children outside of our family and outside of structured church, Jack \& Jill, and deb activities. My mother blamed us for not fitting in and for not being "Black enough." A danger of the smallness of identity is that class differences often keep us from seeing members of our own community.

Katherine and I were the first generation in the Johnson and the Fields families to attend integrated schools. Though my mother worked for Dade County Public Schools, my parents wanted something different for my sister and I than our neighborhood schools. On the one hand, by the mid to late 1970s, new opportunities were open to us that had been unheard of for our elders. On the other hand, there was no roadmap on how to proceed.

My earliest memories of going to school are of The Heritage School in El Portal where I attended nursery school through fourth grade. The student population at the Heritage School was Black and white. A few of the Black students were of Caribbean heritage; but most were African-American. And, we had a small number of Jewish classmates. I remember having only one Latinx classmate in my class; his sister was the only student of Latin American heritage in my sister's class also. I don't recall a significant number of Latinx students in any grades at The Heritage School.

I was fairly well-integrated at The Heritage School and served as a safety patrol. I wore an orange belt over my shoulder and around my waist with a silver badge on the shoulder. Safety patrols were deputized 
to do chores around the school, such as cleaning up the lunch area and supervising the nursery school and kindergarten children after school. We also had dances just for safety patrols. I was excited to attend, but terrified of boys. I watched them from afar as we all avoided eye contact while dancing surreptitiously and alone to Michael Jackson's "Off the Wall" album. In second grade, Alex Haley's "Roots" premiered on primetime television. Before ONTV, a precursor to cable, everyone watched the same three or four television channels. Usually, my classmates and I talked at recess and lunch about what we watched the night before. While "Roots" aired, Black and white students had little to say to each other. When the mini-series was over, we went back to playing together as before. Overall, the school was forward-thinking; we studied Spanish as young as nursery school. We left The Heritage School after I completed fourth grade.

By 1983, for fifth grade, I attended St. Mary's Cathedral School in Little Haiti. St. Mary's was a new and unwelcome experience. There were few white/Anglo or African-American students. Unlike The Heritage School, most of the students were brown, from Latin America and the Caribbean. St. Mary's was a much larger school than The Heritage School with larger classes sizes, as well as larger facilities. The academic rigor was also less than what I was accustomed to; I became valedictorian of my class with very little effort. And, the environment was more violent and chaotic than anything I had ever experienced. Students fought in class, in the bathroom, and on the playground. At Parent's Day, the teacher told Mom jokingly that she should let him paddle me, because I had not gotten $100 \%$ on a test. Other students in my class witnessed the conversation but did not realize it was a joke. They accepted me for a day or two because of it. My mother did not believe that the teacher actually paddled the students, initially with a wooden pointer. When the pointer broke, he paddled students with the two by four that broke off of the base of his podium. When my mother realized that my teacher was one of her former students, our days at St. Mary's were numbered.

Halfway through the year, Katherine and I took entrance exams and had interviews at Carrollton School of the Sacred Heart in Coconut Grove. I learned years later that my mother and grandmother had many conversations about Carrollton before we were admitted. Mom was concerned about the location and its distance from home. Mom has never been comfortable driving at night or on unfamiliar roadways; she does not drive on the highway and was fearful of the tree-lined drive on Main Highway and campus. Katherine and I were clearly crossing into a different world, one that our elders had not and would not have been invited to enter, one for which none of us were prepared.

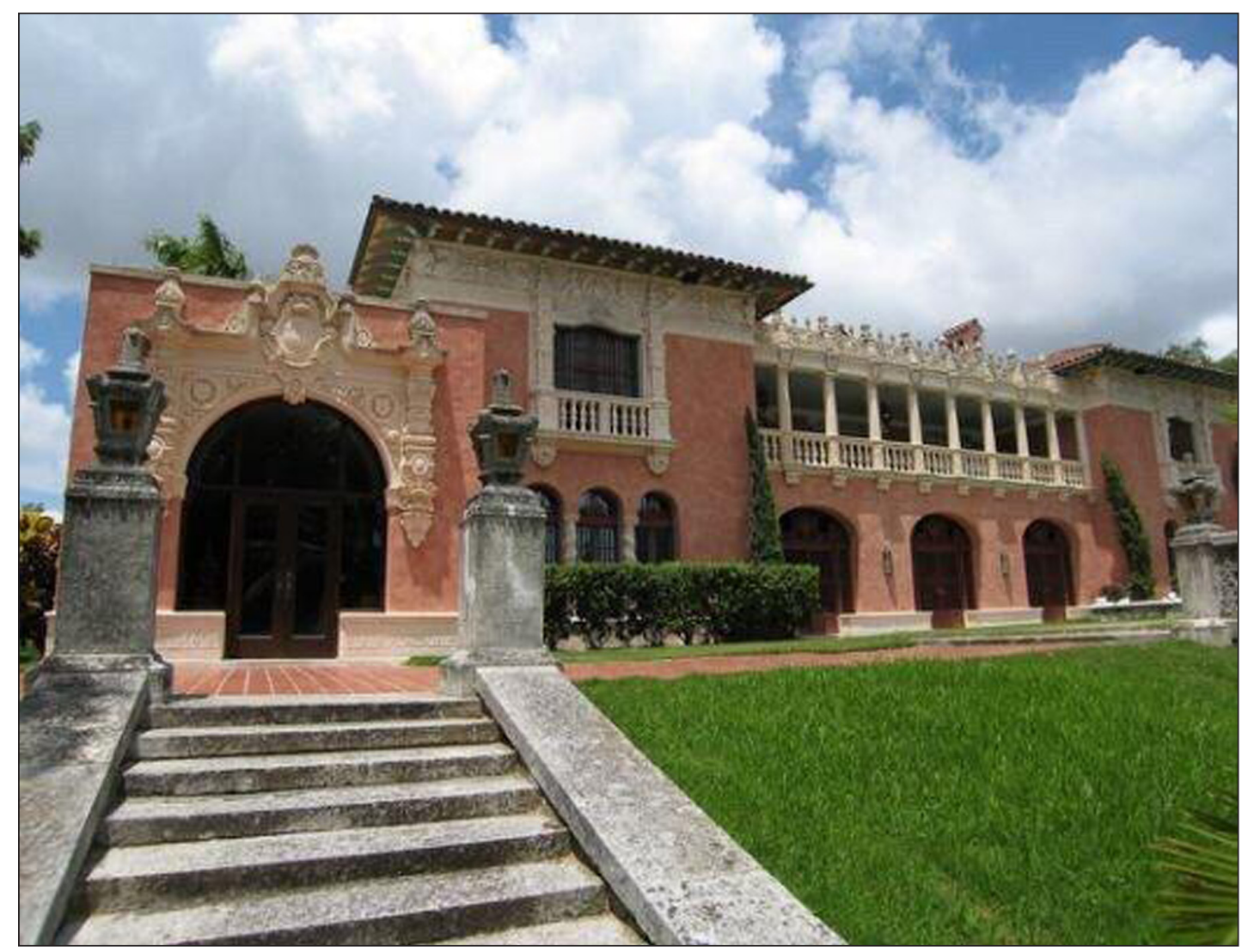

Carrollton School of the Sacred Heart in Coconut Grove. Photo credit www.carrollton.org/. 
Overall, I have fond memories of my middle school and high school years at Carrollton; I had excellent teachers and earned an excellent education. Then again, I am a resilient person who often thrives in the midst of or as a result of adversity. In hindsight, I think I developed some of my resilience at Carrollton. My Dad bussed us to school every day, typically twice a day from our home in Brownsville to Coconut Grove. By the time we got to high school, we carpooled with African-Americans-parents who were my mother's childhood friends and whose daughters attended Carrollton.

In addition to a small number of African-American girls, our classmates were overwhelmingly Latinx students from every corner of Latin America, particularly Cuba, Venezuela, Nicaragua, Columbia, and Argentina. The Black girls were largely from the Caribbean: Haiti, the Bahamas, and Jamaica. African-American, Anglo, and Jewish students were definitely in the minority. While my family considered itself as part of the elite in the African-American community, our wealth was nowhere in the same league as my classmates at Carrollton. They represented Latin America's nouveau riche, many in exile in Miami. And, they regularly exhibited obscene displays of wealth. Rolex watches, Gucci and Louis Vuitton purses, shoes, and outfits were run of the mill on Own Clothes Days. Many of my classmates were given convertible cars for their $15^{\text {th }}$ birthdays; they would drive the car to school with their nannie who would drive it home and come back in the car after school so the girl could drive her car home. For prom and other special occasions, some of my classmates' parents hosted lavish parties staffed by bartenders. Though we made friends, particularly among the other African-American, Caribbean, Anglo, and middle-class girls, we were not allowed to go to the homes of many of our classmates, even if invited. If the girl's mother did not send home a written invitation, if my mother could not talk to her mother on the phone, and if the parents were not going to be home while I was visiting, I could not go. In middle school, some of my best friends lived with and were raised by nannies; their parents lived abroad, all of which were non-starters as far as my mother was concerned. We were not allowed to go to their homes and they never came to Brownsville.

My best friend in high school was Mary Joe Fernandez. When Mary Joe turned pro in tennis in tenth grade, the time she spent out of school and on the tennis circuit increased dramatically. I began helping her mother, Sylvia, organize Mary Joe's assignments. Sylvia and I made sure Mary Joe had all of the notes and handouts she needed to complete her assignments. Then, when she came home, I was happy to be Mary Joe's peer tutor. I learned a lot about tennis from Mary Joe; she tried to teach me to play and invited me to travel with her to some of the tournaments. But, I was not at all athletic in middle school and high school-I did not like to sweat-and my parents would not let me go around the block without their supervision, let alone halfway around the world. They did let me go to and even sleep over at Mary Joe's house, a modest apartment in Kendall in those days. Mary Joe's parents were as strict as mine. Her father traveled with her on the junior and professional circuits. Our fathers trusted and understood each other, though her father did not speak much English and my father did not speak a word of Spanish. They would stand side by side with their hands on their hips, rocking back on their heels and looking protectively over their daughters in the distance, but within their sight. And, once she started winning on the circuit and became the spokesperson for one of the luxury car dealers in Miami, Mary Joe trusted me to drive her Porsche into Coconut Grove with or without her in the car for lunch when Carrollton juniors and seniors had lunch privileges. I do not remember if I even had a driver's license at the time and do not think my parents ever knew, until now. One night, Mary Joe's brother-in-law drove me home. He drove around for about an hour, because I mysteriously could not remember my address. I did not want him to see where I lived.

Class differences at Carrollton were ever present. And, racial tensions were just below the surface. Learning the meaning of "la rubia," the value put on blond hair and blue eyes in Latinx cultures, was one of my first memories of school. Disdain for dark skin, hair, and eyes and kinky hair was on the surface subtler. I was more naïve and less aware of racial micro-aggressions. From dancing to Wilfrido Vargas' "El Africano," I developed a life-long love of merengue music and dance, "El Africano" was one of my favorite songs. Studying critical race theory in college gave me the tools to analyze the lyrics and understand the meaning of "el negro esta rabioso" years later. Colorism in Latinx cultures was reminiscent of my own family. I was the daughter whose coarse, unmanageable hair necessitated my sister and I getting our hair relaxed while we took swimming lessons. This turned out to be a disastrous combination as far as my hair was concerned; I remember it washing down the drain more than once. My coarse, unmanageable hair, not my sister's, also motivated my mother to give us home weaves in honor of us beginning the school year at Carrollton. I remember feeling dark and ugly every day going to school at Carrollton. When I was in high school and our Dad dropped my sister and I off at home, instead of at my grandmother's house, to do our homework and start dinner, I spent many afternoons bathing my skin in lemon juice. I thought lemon juice might lighten my skin as my classmates said it lightened their hair and made them beautiful like "la rubia." My classmates and teachers at Carrollton 
told me I was different, special, and more than Black, not like "el negro rabioso" or the poor Black people who rioted in Brownsville, Liberty City, and Overtown in the 1980s. Until I left Miami and went to college, I believed them. The most dangerous downfall of the smallness of identity is that racial exceptionalism keeps us from seeing ourselves, as well as from seeing each other.

At Governor's School for Screenwriting at Miami-Dade College's New World Campus, I finally met someone like me who gave me the tools to be confident, whether other Black kids in my social groups or my Latinx classmates felt I fit in or not. The African-American girl, my liberator, was from Killian High School. Other Black students in our class taunted both of us for talking and acting white. The Killian Student was comfortable in her own skin. She stood up for herself, lobbing a retort for every accusation. For example, when the other students accused her of talking or acting white; she would reply that's because she was well educated and would one day be their boss. I learned quickly from her how to speak up for myself. It did not take long for the other Black students to leave us alone. I did not learn much about screenwriting that summer, but successfully developed the skills to grow up Black in Miami. These skills would be tested when I went to college and came home during school breaks, frequenting night clubs like Strawberries and Fifth Street with my friends from Carrollton and from Emory. I guess I finally figured things out.

When my son, Akhu, was four years old, I experienced the complexities of raising a child growing up Black in Miami. I wanted our son to learn to speak Spanish; unfortunately, his kindergarten and elementary school in Pittsburgh did not offer foreign language. So, I packed him up and enrolled him in a Spanish immersion camp at University of Miami. I took my father's role, bussing Akhu from Brownsville to and from UM every day. I would stay on campus working in the library, then pick him up, and take him home. Many of the kids at the summer camp knew each other; they returned to the camp year after year. He may have been one of a very few new students. But he wasn't one of the only Black students; then again it all depends how one defines Blackness. I picked Akhu up one afternoon in the first week of camp and found him to be sullen and

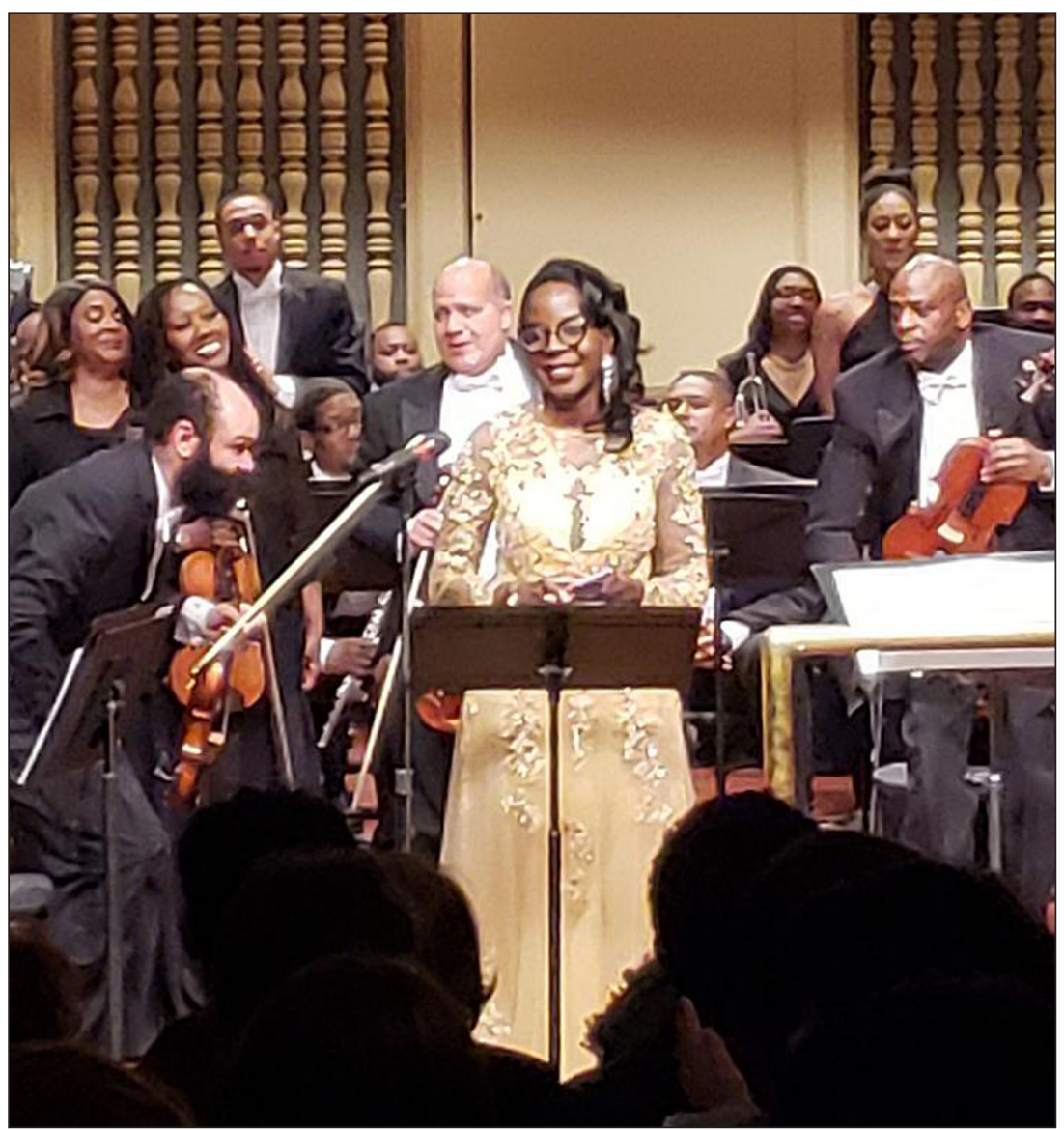

Dr. Edda Fields-Black takes a bow after the presentation of her libretto Unburied, Unmourned, Unmarked: Requiem for Rice with composer John Wineglass, and filmmaker/director, Julie Dash. Photo courtesy of author. 
brooding. When we got back to my Mom's house, he threw his toys on the floor, would not eat his food, and refused to do anything I asked him to do. I knew something must have happened, but did not know what. It took a lot of coaxing for him to tell me that a girl at camp told him his skin was dirty, nasty, and soiled; she told him he needed to bathe. I knew African-American, Caribbean, and Latinx cultures well enough to know that a four-year-old did not come up with this poison on her own; she was repeating what she heard at home. That summer, I came full-circle, spending the remainder of the session at summer camp traversing the terrain I once thought was my backyard, making sure Akhu was OK, and helping him to navigate racialized terrain. I had learned to overcome the smallness of identity; now I had to teach our next generation.

\section{Competing Interests}

The author has no competing interests to declare.

How to cite this article: Fields-Black, E 2020 The Smallness of Identity, Smallness of Blackness. Anthurium, 16(1): 7, 1-10. DOI: https://doi.org/10.33596/anth.365

Published: 31 March 2020

Copyright: ( 2020 The Author(s). This is an open-access article distributed under the terms of the Creative Commons Attribution 4.0 International License (CC-BY 4.0), which permits unrestricted use, distribution, and reproduction in any medium, provided the original author and source are credited. See http://creativecommons.org/licenses/by/4.0/. 